\title{
NOTES ON THE ILLUSTRATIONS
}

JACKET. The ornamental sections derive originally from the title-page illustration to Ranulphus Higden's Polycbronicon, printed by Peter Treveris in Southwark, 1527. In the upper segment, originally displaying the arms of the Tudor monarchs and the city of London, two others more appropriate to this story have now been substituted:

1. Arms of the Early Warwicks: A Bear erect, argent, muzzled gules, supporting a ragged staff of the first. This ensign was created in two stages, (a) by Arthgal-signifying bear in the British language - the earliest consul of Warwick, temp King Arthur and a knight of his Round Table, (b) by Morvi, second consul who vanquished a giant with a tree plucked up by the roots. The cognizance was later assumed, presumably, by the third British consul, Marthrud, and then by the first two Saxon Earls who appear in this romance, Roalt and Guy. Much later, on November 13, 1759, Francis Greville, first Earl Warwick of the present lineage, obtained a special grant to bear the crest of this ancient, and essentially mythical regime.

2. Arms of the Meysey family: Argent a fesse between three cinqfoils sable. To the ladies of this family readers are now indebted for translating, literally into English, this most extensive version of Guy, hitherto secluded in early French.
Title Pages. On the pages immediately following are represented the titles of the original French edition 1525 and the English manuscript copy of 1821. It will be noted that the Meysey ladies chose not to dignify their script cum privilegio. Their act, as noted later (pp. 167-168), was simply con amore.

TEXT. All woodcuts are reproduced (the first two much reduced, the others in original size) from the French edition, and all entered in proper position or as near that position as present typography allows. Besides these, the layout at times requires, in different sizes, two tailpieces, here properly chosen from the standards of the Crusaders:

1. Arms of the Knights Templars: Argent a cross gules and a chief sable. First illustrated on page 6 .

2. Arms of the Knights Hospitallers: Gules a cross argent. First illustrated on page 11.

Apart from these the editor has chosen to display (pp. 38-39) (a) the page from the French edition concluding Chapter 19 and beginning Chapter 20, (b) the page from the English manuscript introducing Chapter 20. That chapter, in the present edition, begins on page 40. 


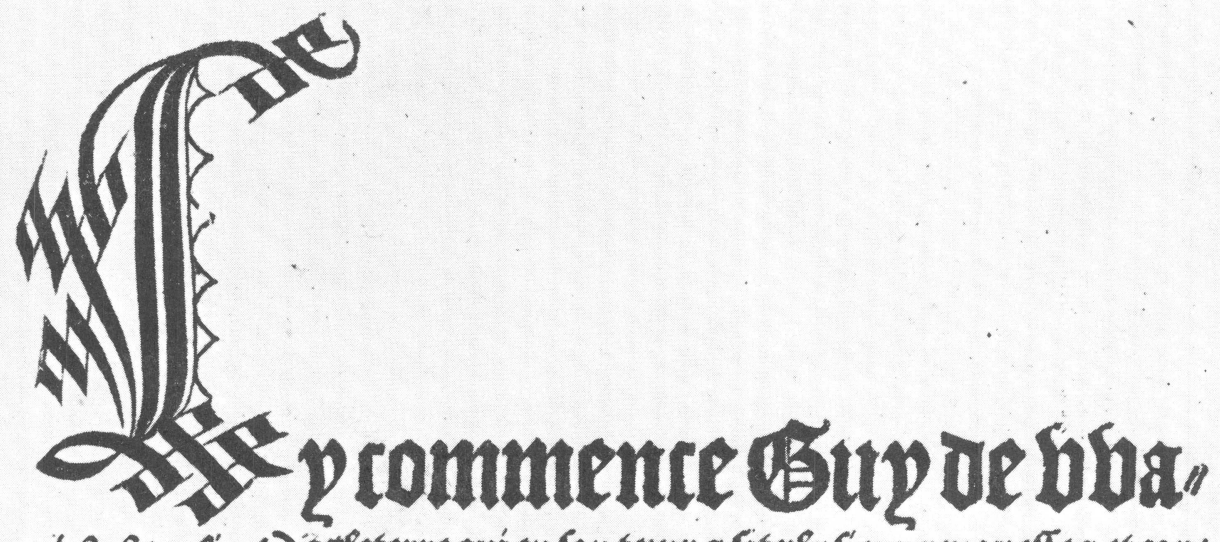

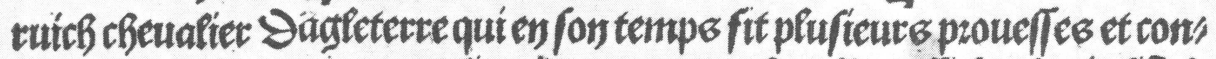

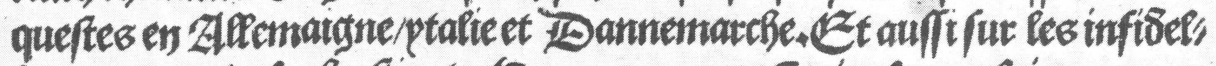
fegennempe delachueftiente (Conme poutres beotrplus aplainencepre'

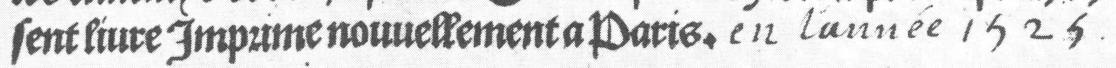

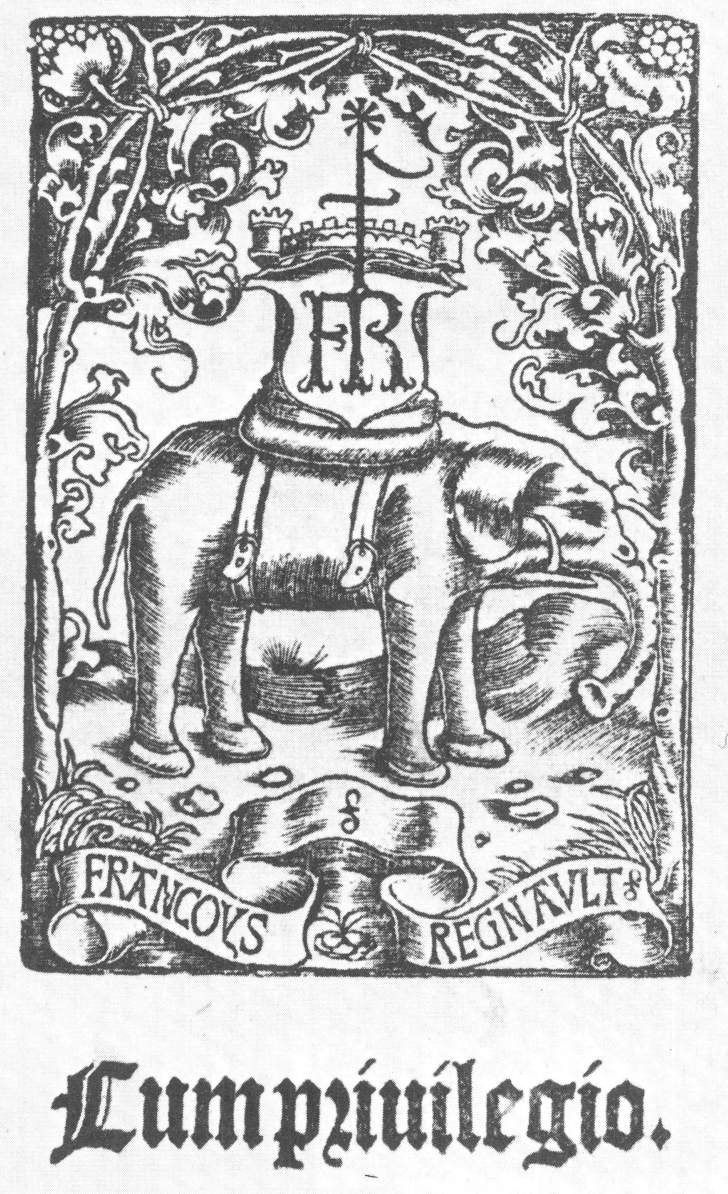




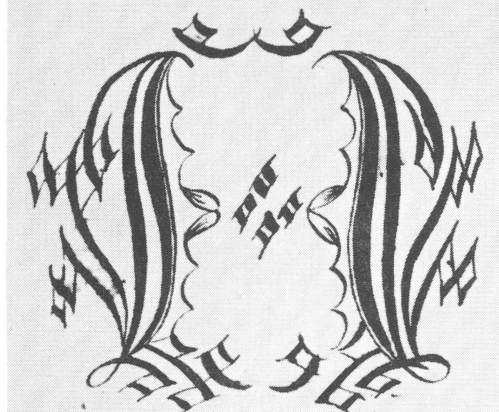

(Gup of boarwick a Fight of Brifain who in lis day did many deeds of prowefs and conquest in Germany Sinfidels, the enemies of eliristionity as may be seen more af large in this present $\$$ sook newly printed at paris.

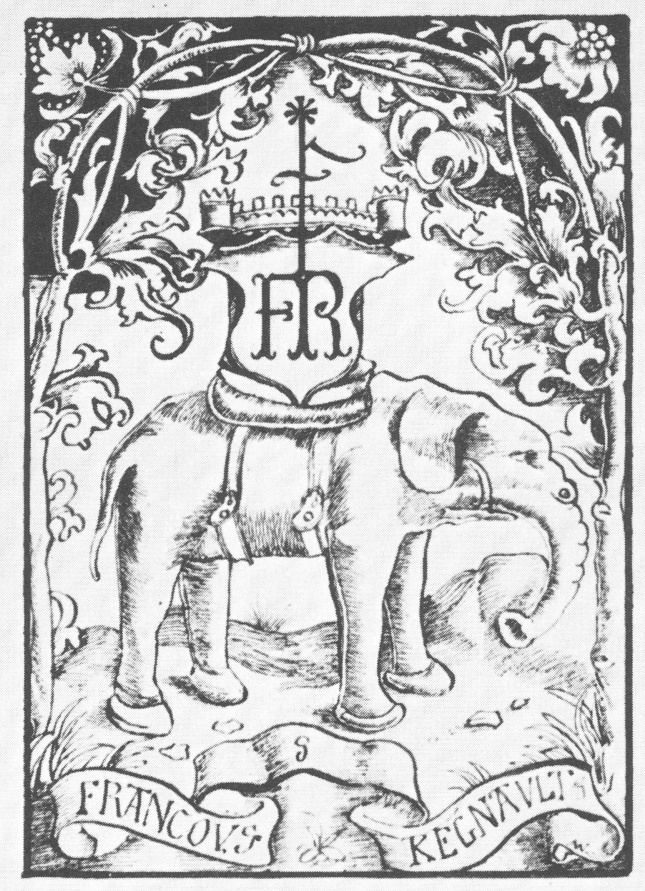

